\title{
Correction to: Congenital infection with Anaplasma phagocytophilum in a calf in northern Germany
}

\author{
Thomas Henniger ${ }^{1}$, Pauline Henniger ${ }^{1}$, Thekla Grossmann², Ottmar Distl ${ }^{1}$, Martin Ganter ${ }^{2}$ \\ and Friederike D. von Loewenich ${ }^{3^{*}}$
}

\section{Correction to: Acta Vet Scand (2013) 55:38 \\ https://doi.org/10.1186/1751-0147-55-38}

Following publication of the original article [1], we have been notified of a typing error under the "Laboratory test results" section.

- Incorrect sentences:

In contrast, the dam was infected with A. phagocytophilum carrying only the ankA gene variant of cluster I in blood samples taken at parturition and 2 days postpartum.

The cluster I ankA sequences of both animals were $100 \%$ identical.

- Correct sentences:

In contrast, the dam was infected with $A$. phagocytophilum carrying only the ankA gene variant of cluster IV in blood samples taken at parturition and 2 days postpartum.

The cluster IV ankA sequences of both animals were $100 \%$ identical.

\begin{abstract}
Author details
${ }^{1}$ Institute for Animal Breeding and Genetics, University of Veterinary Medicine Hannover, Bünteweg 17p, 30559 Hannover, Germany. ${ }^{2}$ Clinic for Swine and Small Ruminants, University of Veterinary Medicine Hannover, Bischofsholer Damm 15, 30173 Hannover, Germany. ${ }^{3}$ Institute of Medical Microbiology and Hygiene, University of Freiburg, Hermann-Herder-Strasse 11, 79104 Freiburg, Germany.
\end{abstract}

The original article can be found online at https://doi. org/10.1186/1751-0147-55-38.

\section{Publisher's Note}

Springer Nature remains neutral with regard to jurisdictional claims in published maps and institutional affiliations.

Received: 28 January 2019 Accepted: 28 January 2019

Published online: 30 January 2019

\section{Reference}

1. Henniger T, Henniger P, Grossmann T, Distl O, Ganter M, von Loewenich FD. Congenital infection with Anaplasma phagocytophilum in a calf in northern Germany. Acta Vet Scand. 2013;55:38. https://doi. org/10.1186/1751-0147-55-38.

\footnotetext{
*Correspondence: friederike.loewenich@uniklinik-freiburg.de

${ }^{3}$ Institute of Medical Microbiology and Hygiene, University of Freiburg,

Hermann-Herder-Strasse 11, 79104 Freiburg, Germany

Full list of author information is available at the end of the article
} 